\title{
選択型コンジョイント分析による北海道産米の属性評価
}

\author{
佐藤 和夫 北海道大学大学院 \\ 岩本博幸 北海道大学大学院 \\ 出村 克彦 北海道大学農学研究科
}

\section{1. 裸題}

本稿の課題は北海道産米の属性評価を，選択型コン ジョイント分析を用いて行うことである. 本稿での北 海道産米の属性とは，消費者が米を購入する際に考唐 すると考えられる，品種，産地，栽培方法などといっ た商品特性をさす。

現在，北海道において飯米として販売されている米 は北海道産米のみに限らず，東北地方を中心とした他 府県産米も流通している. 他県産米が良食味米として 販売展開をしているのに対して, 北海道産米は, 食味 面での向上に加えて他県産米と比べて低農薬であるな どの栽培方法を強調した販売展開を行っている，した がって，消費者は多様な産地·品種·栽培方法などの属 性を考慮して購入する米を選択することが可能となっ ている.こうした中で，米の属性，特に有機栽培ある いは減農薬·無農薬といった付加的な属性の評価を行 うことは，生産側が生産・販売戦略を立てるための情 報を得る手段として有効であると考えられる.

以上から本稿では，具体的に次の 2 点について明 らかにする。

(1)北海道産米に，減農薬・無農薬といった属性を付 加した場合の属性評価を行う。

(2)属性評価より得られた結果をもとに，北海道産米 の他産地米に対する市場競争力についてシミュレ ーション分析を行う.

\section{2. コンジョイント分析}

本稿では，分析方法として選択型 (Choice Based) のコンジョイント分析 (Conjoint Analysis) を用い る. コンジョイント分析は 1960 年代に計量心理学分 野で開発された。経済学分野では 1970 年代以来，主 にマーケティング・リサーチに応用され，商品選好の 属性別推定を行う手法として利用されている（コンジ ヨイント分析の詳細については，例えば栗山[6]を参 照).

今回用いた選択型コンジョイント分析は，属性の異 なる複数の商品の中から，最も好ましいものを選んで もらうという質問形式を用いる．選択型の質問は，市 場における購買行動に類似した形態であり，「どれも 選ばない」という選択肢を含めることができるなど，
回答者に与える負担が比較的小さい，

国内の農業経済学分野におけるコンジョイント分析 の既存研究には，米の属性評価を行った平尾[2]，認 定農業者の支援プログラムを対象とした栗原・丸山[5] がある。

\section{3. アンケート調查概要}

アンケートは NTT の電話帳からランダムに抽出し た，札幌在住の 200 名を対象としている，調查では Mangione [8], Adamowicz et. al. [1]を参考として, 督促状と回答者への謝礼によって回収率の向上を目指 した. 実配布数 184 のうち 106 通を回収したが，計 測には回答不備を除いた 103 サンプルを使用した. 有効回答率は $56.0 \%$ であり, ランダム・サンプリン グによる郵送調查としては，かなり高い回答率が達成 されたといってよいだろう.

\section{4. プロファイル・デザイン}

米の属性のうち, 本稿で評価対象としたのは, 表 1 の 4 属性である. これらの属性を決めるにあたって は, 調查直前に行った小売店における価格調查の知見 を利用するとともに，専門家の意見を取り入れている．

まず，「品種」については，北海道産米の代表的品 種である「きらら 397」と「ほしのゆめ」に加え，上 位の競合品種として「茨城産コシヒカリ」と「秋田産 あきたこまち」を設定した，後者の 2 品種は，札幌の 小売店での流通量が豊富であることと，特売時には道 産米と競合品種となるという条件から選定した。栽 培方法」には，農林水産省の「有機農産物および特別 栽培農産物にかかわる表示ガイドライン」に準じた 3

\begin{tabular}{|c|c|}
\hline 品種 & \begin{tabular}{|l} 
(1) 北海道産きらら397 \\
(2) 北海道産ほしのゆめ \\
(3) 茨城県産コシヒカリ \\
(4) 秋田県産あきたこまち
\end{tabular} \\
\hline $\begin{array}{l}\text { 産地・ } \\
\text { 生産者名 } \\
\text { の表記 }\end{array}$ & $\begin{array}{l}\text { (1) なし（都道府県名のみ） } \\
\text { (2) 市町村名を明記 } \\
\text { (3) 市町村名と生産者名を明記 }\end{array}$ \\
\hline 栽培方法 & $\begin{array}{l}\text { (1) 通常の栽培方法 } \\
\text { (2) 減農桼・減化学肥料 } \\
\text { (3) 無農蘶・無化学肥料 } \\
\text { (4) 有機栽培 }\end{array}$ \\
\hline 価格 & 2,980 円 $-5,480$ 円 (500円刻み) \\
\hline
\end{tabular}


段階に，通常の栽培方法を含めて 4 段階を設定した (注 1).

アンケート票では，4 属性を1つの商品特性（プロ ファイル) とし，にの中ではどれも買わない」を含 む4つの「商品」から，回答者に選択を求める(図 1). この「選択実験」を各回答者に 8 回行ってもらった ため，分析に用いるサンプル数は回収アンケート数の 8 倍になる. 本稿の約 800 サンプル（100人の回答者 に各 8 回の質問）というサンプル数は，選択型コンジ ヨイント分析においてはスタンダードなものである (Huber and Zwerina[3]).

\begin{tabular}{|c|c|c|c|c|}
\hline 番号 & 1 & 2 & 3 & 4 \\
\hline 品種 & $\begin{array}{l}\text { 茨城産 } \\
\text { ヨシヒカリ }\end{array}$ & $\begin{array}{l}\text { 道内産 } \\
\text { きら55397 }\end{array}$ & $\begin{array}{c}\text { 秋田産 } \\
\text { あきたたち }\end{array}$ & \multirow{4}{*}{$\begin{array}{c}\text { この中では } \\
\text { どれも } \\
\text { 賽わない }\end{array}$} \\
\hline 表記 & なし & $\begin{array}{l}\text { 市町村名まで } \\
\text { 明記 }\end{array}$ & $\begin{array}{c}\text { 生産者名·市町 } \\
\text { 村名を明記 }\end{array}$ & \\
\hline $\begin{array}{l}\text { 栽培 } \\
\text { 方法 }\end{array}$ & 通常の载培方法 & $\begin{array}{c}\text { 减農策. } \\
\text { 娍化学肥料 }\end{array}$ & $\begin{array}{c}\text { 無農菓· } \\
\text { 無化学肥料 } \\
\end{array}$ & \\
\hline 価格 & $\begin{array}{ll}3,480 \text { 円 } & (10 \mathrm{~kg}) \\
1,740 \mathrm{H} & (5 \mathrm{~kg})\end{array}$ & $\begin{array}{l}3,480 \mathrm{H}(10 \mathrm{~kg}) \\
1,740 \mathrm{P}(5 \mathrm{~kg})\end{array}$ & $\begin{array}{l}4,980 \mathrm{P}(10 \mathrm{~kg}) \\
2,490 \mathrm{P}(5 \mathrm{~kg})\end{array}$ & \\
\hline
\end{tabular}

本稿で採用している選択型を含め, コンジョイント 分析では「プロファイル・デザイン」が極めて重要で ある. 最も基本的なデザインは，直交配列表を用いた 直交デザインだが，これには非現実的な選択肢が多く 混ざってしまうなどのデメリットもある.

Huber and Zwerina [3]は，デザインの効率性につ いて, この直交性 (orthogonality) を含めて 4 つの

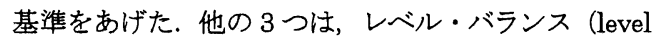
balance：各属性のレベルが，質問に等しく登場する こと)，ミニマル・オーヴァーラップ (minimal overlap : 各質問において，それぞれの属性の同じレ ベルが最小限しか登場しないこと），選択肢間の効用 バランス (utility balance : 各選択肢の選択確率に著 しい差がないこと）である. Huber らは，D-error の 最小化によって，これらの基準を同時に最適化するこ とができるとし，プロファイル・デザインに事前情報 を反映させることを提唱した，本稿では，Huber ら の方法を発展させた Zwerina, Huber and Kuhfeld[9] の方法を用い，事前情報として予備調査の計測結果を 用いることで，推定精度を高めることを試みている(注 2).

\section{5. モデル}

選択型コンジョイント分析のデータは，ランダム 効用理論と整合性をもつ．選択肢 $\mathrm{i}$ を選んだときの効
用 $U_{i}$ が，観察可能な要因で決定される部分 $V_{i}$ と観察 不能な(そのため確率的に決まるとみなされる)部分 $\varepsilon_{\mathrm{i}}$ から構成されるとすると， $U_{i}$ は以下のようにあらわ すことができる.

$$
\mathrm{U}_{\mathrm{i}}=\mathrm{V}_{\mathrm{i}}+\varepsilon_{\mathrm{i}} \text {. }
$$

このとき，選択肢 i が選ばれる確率 P （i）は，全 ての選択肢の集合をCとするとき，

$$
P\{i\}=P\left\{V_{i}+\varepsilon_{i}>V_{j}+\varepsilon_{j} ;{ }^{\forall} j \in C(i \neq j)\right\} .
$$

とあらわされる。

$\mathrm{V}_{\mathrm{i}}$ には各属性が含まれ，4つの選択肢（3つのプロ ファイルと「この中ではどれも買わないり）がある． 誤差項をガンベル分布として IIA の仮定をおくと， 選択肢 i が選択される確率は,

$$
\mathrm{P}\{\mathrm{i}\}=\mathrm{e}^{\mathrm{sVi}} / \Sigma \mathrm{e}^{\mathrm{sVj}}{ }_{\mathrm{j}} \in \mathrm{C}
$$

とあらわされる. ただしsはスケール・パラメータで あり，通常は 1 と仮定される.

本稿では，この $\mathrm{V}_{\mathrm{i}}$ の関数型として，最も一般的な 線型を用い，Conditional Logit Modelによって計測 を行った.

\section{6. 計測結果}

計測結果を表 2 に示した (注 3)。推定パラメータ は，選択確率一の影響を表すため，価格は負，その他 の属性は全て正の符号が期待されるものであり，符号 条件は全て満たされている， $\mathrm{t}$ 值から判断した各推定 パラメータの有意性も十分な水準であり，モデル全体 のフィットを示す修正 $\rho^{2}$ も 0.254 と十分に高いもの となっている (注 4).

パラメータの大きさについてだが，まず，品種ダ ミーについては「秋田産あきたこまち」が最も高く，

「茨城産コシヒカリ」が続き，北海道産米 2 品種は ほぼ同じ值である，食味では「きらら 397」を上回る といわれている「ほしのゆめ」だが，知名度では「き らら 397」が勝っていることを反映していると考えら れる. この 4 品種のパラメータの大きさの差異は, 現実の市場における価格差をほぼそのまま反映したも のとなっている.

産地・生産者名の表記についても，BB2（市町村 名を明記）<BB3（市町村名・生産者名を明記）と なっており，事前の予想に一致する結果となった.

栽培方法では，BS2（減農薬・減化学肥料）と BS3 
表2. 計測結果

\begin{tabular}{|c|c|c|c|c|c|c|}
\hline パラメータ & 区分 & 意味 & 推定值 & 標準誤差 & $t$ 值 & p值 \\
\hline $\mathrm{BH} 1$ & \multirow{4}{*}{ 品種 } & 北海道産きらら397 & 2.84718 & 0.34284 & 8.30482 & 0.000 \\
\hline $\mathrm{BH} 2$ & & 北海道産ほしのゆめ & 2.83599 & 0.34951 & 8.11423 & 0.000 \\
\hline $\mathrm{BH} 3$ & & 茨城県産コシヒカリ & 3.39032 & 0.35636 & 9.51382 & 0.000 \\
\hline $\mathrm{BH} 4$ & & 秋田県産あきたこまち & 3.60712 & 0.39997 & 9.01855 & 0.000 \\
\hline $\mathrm{BB} 2$ & \multirow{2}{*}{$\begin{array}{c}\text { 生産地·生産者 } \\
\text { の表示 }\end{array}$} & 市町村名を明記 & 0.32960 & 0.11733 & 2.80913 & 0.005 \\
\hline BB3 & & 市町村名·生産者名を明記 & 0.38518 & 0.10088 & 3.81815 & 0.000 \\
\hline $\mathrm{BS} 2$ & \multirow{3}{*}{$\begin{array}{l}\text { 栽培 } \\
\text { 方法 }\end{array}$} & 減農薬·減化学肥料 & 1.00554 & 0.14958 & 6.72259 & 0.000 \\
\hline BS3 & & 無農薬·無化学肥料 & 1.44641 & 0.16078 & 8.99603 & 0.000 \\
\hline BS4 & & 有機栽培 & 1.40306 & 0.16784 & 8.35968 & 0.000 \\
\hline $\mathrm{BP}$ & 価格 & 価格 & -0.00064 & 0.00010 & -6.65850 & 0.000 \\
\hline \multicolumn{2}{|c|}{ summary statistics } & $\begin{array}{c}\text { サンプル数 } \\
\text { Log-likelihood } \\
\rho^{2} \\
\text { 修正 } \rho^{2} \\
\end{array}$ & \multicolumn{2}{|c|}{$\begin{array}{c}822 \\
-992.702\end{array}$} & & \\
\hline
\end{tabular}

注) 価格以外の変数はダミーである。

（無農薬・無化学肥料）の関係は, BS2 $<$ BS3 とな っており，整合的である，しかし，「無農薬・無化学 肥料」を包含する栽培方法である「有機栽培」のパラ メータ（BS4）は BS3 とほぼ等しく，わずかに下回 っている.これは「3 年以上化学肥料などを使ってい ない水田で栽培する」という，ここでの「有機栽培」 が十分に評価されていないという結果であり，「有機 栽培」のメリットについて，消費者の理解が十分でな いことを反映していると考えられる.

\section{7. シミュレーション}

以下では，北海道産米の市場競争力を分析する（注 5)，具体的には，前節の計測モデルを用いて，各商 品間で消費者の購入確率が等しくなる条件（価格およ び付加属性）を，シミュレーションにより明らかにす る. なお, 北海道産 2 品種の計測結果が似通ったも のであることから，「きらら 397」を中心に分析する.

\section{（1）価格条件のみによる北海道産米の市場競争力}

まず，付加的な属性（無農薬など）がない場合の 競争力をシミュレートした（表 3).「きらら 397」が 調查時の札幌市における標準的な価格の $10 \mathrm{~kg} 2,980$ 円であるとして，他の品種がいくらであれば消費者の 購入確率が等しくなるかを求めている、結果は「茨城

表3. 価格条件のみによる北海道産米の市場競争力

\begin{tabular}{|c|c|c|c|c|}
\hline & $\begin{array}{c}\text { 北海道産 } \\
\text { きら5 } \\
397 \\
\end{array}$ & $\begin{array}{c}\text { 北海道産 } \\
\text { ほしのゆ } \\
\text { め }\end{array}$ & $\begin{array}{l}\text { 茨城県産 } \\
\text { コシヒカリ }\end{array}$ & \begin{tabular}{|c|} 
秋田県産 \\
あきた \\
こまち
\end{tabular} \\
\hline 栽培方法 & 通常 & 通常 & 通常 & 通常 \\
\hline $\begin{array}{c}\text { 市町村名· } \\
\text { 生産者名 } \\
\text { の表示 }\end{array}$ & なし & なし & なし & なし \\
\hline 価格 (円) & 2,980 & 2,962 & 3,834 & 4,176 \\
\hline
\end{tabular}

注)価格は10 kgあたり
県産コシヒカリ」が 3,834 円，「秋田県産あきたこま ち」が 4,176 円となった.この結果を「3,834 円の茨 城産コシヒカリと 2,980 円のきらら 397 は，(平均的 な）消費者にとって無差別になる」と読むことができ る.これらの值は調査地域における両品種の実勢価格 とかなり近い. 実勢価格での各商品の売れ行きが均等 と考える理由はないが，商品価格はある程度バランス をとった設定がなされていることを考虑すれば，この 結果はモデルに一定の妥当性があることを支持すると いえるだろう。

（2）属性を付加した場合の北海道産米の市場競争力 表 4 は 10kg3,980 円の「秋田県産あきたこまち」 をべースとして，「きらら 397」に付加的な属性が加 わった場合に，この秋田県産あきたこまち」と選択 確率が等しくなる価格を求めた結果である。これによ ると，10kg3,980 円の「秋田県産あきたこまち」に対 して，価格のみによるアピールで同程度に「きらら 397」を売ろうとすれば, 2,784 月というかなり低い 価格をつけなければならない, しかし, 「減農薬・減 化学肥料」という属性が加われば，ベースのあきたこ まちを超える価格設定をしても，同程度以上の商品ア ピールを期待できるという結果になっている.

\section{8. おわりに}

本稿では選択型のコンジョイント分析を用いて， 北海道米の多属性評価と市場競争力についてのシミュ レーション分析を行った. 主たる結論は, 以下の 2 点である.

(1)北海道産米に付加する属性として取り上げたう

ち, 農薬・化学肥料の使用量の減少, および産 地 (市町村名) ・生産者名の明示が, 商品価值を 
表4.属性を付加した場合の北海道産米の市場競争力

\begin{tabular}{|c|c|c|c|c|c|c|}
\hline 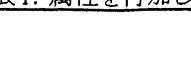 & $\begin{array}{l}\text { 秋田県産 } \\
\text { あきたこち }\end{array}$ & \multicolumn{5}{|c|}{ 北海道産きらら397 } \\
\hline 栽培方法 & 通常 & 通常 & $\begin{array}{l}\text { 減農薬· } \\
\text { 减化学肥料 }\end{array}$ & $\begin{array}{l}\text { 無農薬. } \\
\text { 無化学肥料 }\end{array}$ & $\begin{array}{l}\text { 減農薬・ } \\
\text { 減化学肥料 }\end{array}$ & $\begin{array}{c}\text { 無農薬· } \\
\text { 無化学肥料 }\end{array}$ \\
\hline $\begin{array}{c}\text { 市町村名・ } \\
\text { 生産者名の表示 }\end{array}$ & なし & \multicolumn{3}{|c|}{ なし } & \multicolumn{2}{|c|}{$\begin{array}{c}\text { 市町村名·生産者名を } \\
\text { 明記 }\end{array}$} \\
\hline 価格 (円) & 3,980 & 2,784 & 4,366 & 5,060 & 4,972 & 5,666 \\
\hline
\end{tabular}

高めることが実証的に示された. ただし、「3 年 以上化学肥料などを使っていない水田で栽培す る」という,ここでの「有機栽培」と,「無農薬・ 無化学肥料」の評価はほぼ等しいという結果と なった.これは「有機栽培」のメリットについて, 消費者の理解が十分でないことを反映している と考えられる.

(2)シミュレーションからは, 現状の北海道米はか なり低い価格を設定しなければ，他府県の優良 食味米に対抗できないものの, 「減農薬・減化学 肥料」などの属性を付加することによって，価 格面でも同等あるいはそれ以上の商品アピール が発揮されることが示された。

本稿は札幌市内という限定された地域における調 査であり，またコスト面での検討も行っていないが， この結果は「低農薬」を推し進めようという北海道米 の販売展開に詨して, 肯定的なものである.

\section{注}

1）農林水産省のガイドラインについては，回答者の認知度が低 い可能性があるため, アンケート前段に“Warm Up Question”を設けることで，認識を深めてもらうよう試みた。

2) プロファイル・デザインの方法については, 早稲田大学栗山 浩一氏から有益な示唆を受けた。記して感眼したい.なお, プロファイル・デザインにおける D-error の計算・最適化に は, Microsoft Excel97に VBAを組み合わせた簡易プログラ ムを開発して利用した。

3）計測には計量経济学用の統計パッケージソフト TSP ver 4.4 を用いた。

4) Hensher and Johnson[4]によれば, Discrete model の場合, この值が 0.2 以上であれば, フィットとしてはよい部類に入 るという.

5）ここでは市場競争力を，商品購買時の選択確率を基にした商 品アピールの相対的な大きさによって判断している. この選 択確率は，栗山・石井[5]のようにマーケット・シェアの分析に 利用することも可能なものだが，今回の対象財である米は価 格や流通に季節変動が大きいことから，マーケット・シェア分 析は行っていない.
注) 価格は10kgあたり

\section{<引用文献>}

[1] W. Adamowicz, P. Boxall, M. Williams, and J. Louviere, "Stated Preference Approaches for Measuring Passive Use Values: Choice Experiments and Contingent Valuation", American Journal of Agricultural Economics, 80 (1998),64-75.

[2] 平尾正之「マーケティング戦略とその支援モデ ル」松原茂昌編著『戦略的農業のための意思決定』， 農林統計協会, 1997,165-180.

[3] J. Huber and K. Zwerina, "The Importance of Utility Balance in Efficient Choice Designs.", Journal of Marketing Research, 33 (1996),307317.

[4] D. A. Hensher and L.W. Johnson, "Applied Discrete Choice Modeling", 1981, John Wiley and Sons, New York.

[5] 栗原伸一・丸山敦史「認定農業者のための効率的 支援活動プログラムの策定ーコンジョイント分析 による選好把握とその適応一」『農業経営研究』 36-2 (1998),35-44.

[6] 栗山浩一「環境評価の現状と課題」，热田豊明・栗 山浩一・竹内畫司編著『環境評価ワークショップ』, 築地書館, 1999, 25-45.

[7] 栗山浩一・石井寛「リサイクル商品の環境価值と 市場競争カーコンジョイント分析による評価一」

『環境科学会誌』, 12-1 (1999),17-26.

[8] T. W. Mangione, "Mail Survey Improving the Quality",1995（林英夫監訳『郵送調査法の実 際』,1999, 同友館）.

[9] K. Zwerina , J. Huber and W.F. Kuhfeld, "A General Method for Constructing Efficient Choice Designs." , 1996, mimeo. 